\title{
Relational Capital and Performance: Empirical Evidence on the Services Sector of SMEs in Malaysia
}

Salwa Muda, Musliha Musman, Amariah Hanum Husin, Raziah Bi Mohamed Sadique, Asma' Rashidah Idris

To Link this Article: http://dx.doi.org/10.6007/IJARAFMS/v12-i1/12010 DOI:10.6007/IJARAFMS /v12-i1/12010

Received: 11 November 2021, Revised: 18 December 2021, Accepted: 29 December 2021

Published Online: 16 January 2022

In-Text Citation: (Muda et al., 2022)

To Cite this Article: Muda, S., Musman, M., Husin, A. H., Sadique, R. B. M., \& Idris, A. R. (2022). Relational Capital and Performance: Empirical Evidence on the Services Sector of SMEs in Malaysia. International Journal of Academic Research in Business and Social Sciences, 12(1), 98-130.

Copyright: (c) 2022 The Author(s)

Published by Human Resource Management Academic Research Society (www.hrmars.com)

This article is published under the Creative Commons Attribution (CC BY 4.0) license. Anyone may reproduce, distribute, translate and create derivative works of this article (for both commercial and non-commercial purposes), subject to full attribution to the original publication and authors. The full terms of this license may be seen at: http://creativecommons.org/licences/by/4.0/legalcode

Vol. 12, No. 1, 2022, Pg. 119 - 130

Full Terms \& Conditions of access and use can be found at http://hrmars.com/index.php/pages/detail/publication-ethics 


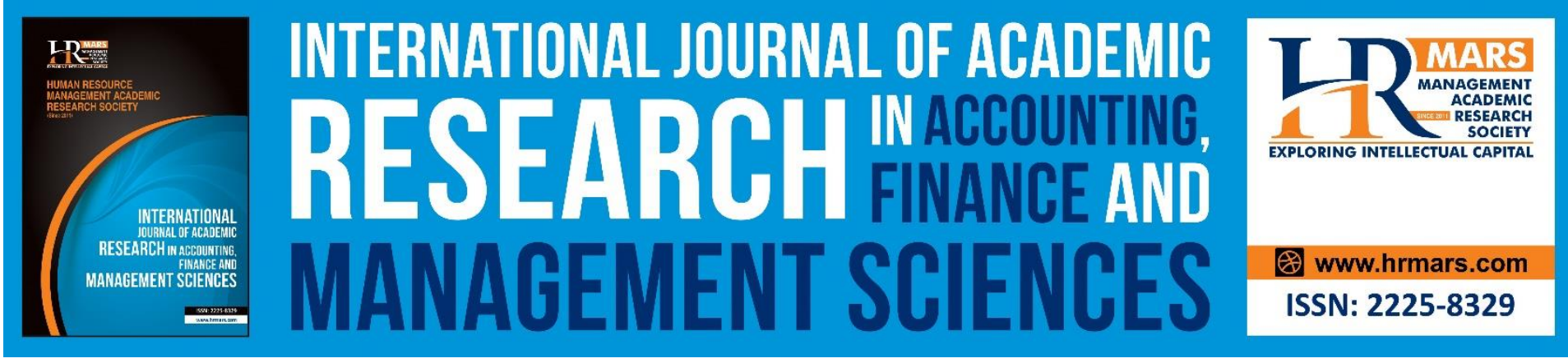

\title{
Relational Capital and Performance: Empirical Evidence on the Services Sector of SMEs in Malaysia
}

\author{
Salwa Muda, Musliha Musman, Amariah Hanum Husin, Raziah \\ Bi Mohamed Sadique \\ Faculty of Accountancy, Universiti Teknologi MARA, Negeri Sembilan, Malaysia
}

\author{
Asma' Rashidah Idris \\ Faculty of Business Management, Universiti Teknologi MARA, Negeri Sembilan, Malaysia \\ Corresponding Email: salwa542@uitm.edu.my
}

\begin{abstract}
Many studies have examined the effect of relational capital on SMEs. However, most studies were done in SMEs, not specific by sectors or industries. Relational capital is expected to have a different impact on the services sector due to its unique characteristics. Moreover, for SMEs to achieve a competitive advantage, SMEs in the service sector need to utilize the knowledge sharing and resources they possess fully. Due to this lack, this study aims to examine the relationships between relational capital and the performance of service SMEs in Malaysia. The survey questionnaire distributed to the SME managers consists of demographic profiles of the respondents and firms' characteristics and items measuring relational capital, including customers, suppliers, distribution channels, the government, and financial institutions. This study revealed that relational capital measured by customers, suppliers, partners, distribution channels, and financial providers significantly influence SMEs' economic and financial performance. Therefore, the findings suggested that the owner or manager of SMEs in the service industry should invest in building and maintaining close relationships with the networks to continuously serve the nation and contribute to the economies.
\end{abstract}

Keywords: Relational Capital, Intellectual Capital, Performance, SMEs, Services Sector.

\section{Introduction}

Today's competitive environment in a knowledge-based economy witnesses the rise of the effective utilization of intangible assets, which allow value to be created for products and services. The emergence of the knowledge economy and the importance of innovation as a determinant of competitiveness are changing the market requirements and leading firms to face new challenges and risks. Hence, firms' value creation in this complex and uncertain economy relies on knowledge-based assets to complement physical and financial resources as a source of competitive advantage. Outweigh the role of tangible assets, intangible assets and capabilities play a predominant role in bringing firms into the next level of competition in 
MANAGEMENT SCIENCES

Vol. 12, No. 1, 2022, E-ISSN: 2225-8329 @ 2022 HRMARS

many aspects, including innovation, entrepreneurship, and performance in line with the needs of rapidly changing economy (Aziz et al., 2019; Abd-Elrahman \& Kamal, 2020; Febrian et al., 2020). Intellectual capital is frequently used for intangible assets, comprising three main dimensions: human capital, structural capital, and relational capital. This refers to the knowledge embedded in the employees, systems, and relationship with outside parties (Bontis, 1998; Sveiby,1997).

According to the resource-based theory (RBV), a firm's sustainable competitive advantage stems from resources that are valuable, rare, inimitable, and non-substitutable (Barney 1991). Barney (1991) claimed that the firms' resources offer a competitive advantage and the sustained competitive advantage that could be achieved through heterogeneity and immobility of resources and capabilities. Through the effective and efficient utilization of these resources, firms can create competitive advantages and survive in the highly aggressive economic environment. Notably, the firm resources that are specific and not tradable are represented by the knowledge residing in the employees, the systems and structure of the business, and the knowledge embedded in the networks. These resources are primary determinants of firm performance and enable firms to achieve sustainable competitive advantage.

In the case of small and medium-sized businesses (SMEs), relational capital is an essential element for SMEs in building networking with parties outside SME in enhancing the business performance, and they place more value on relational capital than do larger firms (Febrian et al., 2020; Khalique et al., 2015). The knowledge embedded within the relationship between SMEs and customers, suppliers, partners, financial institutions, and other stakeholders helps SMEs add value to the business and increase investors' interest to remain as industry players in their respective sectors. SMEs are widely known to lack physical and financial resources; hence, they need to complement their knowledge and capabilities instead of solely relying on internal processes. Despite the constraints in many aspects, relational capital tends to be more relevant in smaller companies because they are aware of limited resources and thus have more incentives towards negotiating and collaborating with other stakeholders, which might lead to different effects of relational capital compared to larger firms (Welbourne, 2008; Daou et al., 2014; Jain et al., 2017). SMEs appreciate the relationships with customers, suppliers, and financial institutions whenever they need advice regarding their strategies to pursue better achievement (Peltier \& Naidu, 2012). Sharing and acquiring knowledge between SMEs and customers are less complicated, occur very fast, and enable firms to penetrate a broader market (Marzo \& Scarpino, 2016). Importantly, small size provides an opportunity for SMEs better to know the profiles and needs of their customers, thus helping SMEs plan and execute strategies to suit the customers' demands.

As a backbone of the economies across the world, SMEs play a crucial role in employment, gross domestic product, poverty alleviation, and export and import activities. Essentially, relational capital is a critical measure in ensuring SMEs' success despite the resource and structural constraints. Many studies have examined the effect of relational capital on SMEs. However, most studies were done in SMEs, not specific sectors or industries. Relational capital is expected to have a different impact on the services sector due to its unique characteristics. Characterized as establishing close interaction with customers and other stakeholders, combining knowledge into the value of sound systems, and utilizing ICT in their 
MANAGEMENT SCIENCES

Vol. 12, No. 1, 2022, E-ISSN: 2225-8329 @ 2022 HRMARS

daily routines might provide different insights from other sectors such as manufacturing (Kianto et al., 2010). Importantly, SMEs in the service sector need to fully utilize knowledge sharing and resources to compensate for their physical and financial capital drawbacks to achieve a competitive advantage.

Since services business deals with heterogeneity that involves different people and does not have physical products that the customer can see, the reliance on social negotiation skills and intimate relationships with stakeholders are crucial. With the latest pandemic event, which has impacted the service sectors negatively, understanding this relationship is more vital now than before. The lack of research on the effect of relational capital in the service sector still exists, increasing the need to study this relationship and understand how it could help SMEs be sustainable. Therefore, this study aims to examine the relationships between relational capital and the performance of service SMEs in Malaysia.

\section{Literature Review}

Intellectual capital embodies the collection of all knowledge-related and value-creating resources for companies, namely human capital, structural capital, and relational capital, in supplementing physical assets. These three dimensions represent the knowledge that resides in people and the company's members, organizational processes and structures, and relationships with customers and other external networks (Bontis, 1999). As one of the primary components of intellectual capital, relational capital plays a vital role in bridging the organizations with other businesses through knowledge, trust, and transparency, especially in the case of small companies (Saxena, 2015). Relational capital refers to developing relationships and understanding between organizations and external parties in creating organizational value. Relational capital is the knowledge embedded in market channels, customer and suppliers' relationships, the government and industry associations (Bontis, 1999). Broad categories of the firms' external relationships with the stakeholders include customers, suppliers, shareholders, customer loyalty, company names, distribution channels, collaborations, licensing agreements, favorable contracts, and franchising agreements (Petty and Guthrie, 2000; Sveiby, 1997).

According to Capello and Faggian (2005), relational capital comprises market relationships, power relationships, and cooperation established between firms, institutions, and people that stem from a strong sense of belonging and a highly developed cooperation capacity typical of culturally similar people and institutions. The willingness of the organizations to engage in the association with external chains helps firms obtain valuable knowledge regarding the products, industry, and market, which can be used to enhance firm performance. The scope of expertise involved in the relationship is not limited only to product knowledge. The knowledge embedded in the relationships among the firm and external stakeholders is developed through educating the customers about the products, involving customers and suppliers in product planning and development, conducting product seminars, enhancing the systems and data related to customer complaints, and providing effective systems and procedures in communication with external stakeholders (Sveiby, 2001).

Developing the connection with diverse external groups requires a significant amount of time and effort and needs to be maintained over time; however, firms with the capability to extract knowledge from their external constituencies may enjoy higher value creation than their 
MANAGEMENT SCIENCES

Vol. 12, No. 1, 2022, E-ISSN: 2225-8329 @ 2022 HRMARS

competitors (Bontis, 1999). The dependencies on relational capital in today's economy represent the need for the organization to invest in intellectual components that can enhance the capabilities of individuals and organizations in helping the nation's economy (AbdElrahman and Kamal, 2020; Kamukama, 2013).

The firms' emphasis on building close connections with its networks offers many benefits, including enhancing innovation, better cost allocation, improving learning, networks, and business performance (Cabrita \& Bontis, 2008; Wang et al., 2014). Many studies conclude that a great advantage from membership of a network is accessing and utilizing external resources that can be used to enhance the firm's performance. The long-term relationships with acquaintances provide firms with a strong base in achieving competitive advantage, innovation, internationalization, and organizational performance (Abd-Elrahman and Kamal, 2020; Cabrilo et al., 2020; Kamukama, 2013; Yaseen et al., 2016).

\section{SMEs in Malaysia}

SMEs in Malaysia can be distinguished from large enterprises according to the basis of their size, the sales, or number of employees measures that. For the manufacturing sector, the number of full-time employees must not exceed 200, or the sales turnover is limited to RM50 million. For services and other sectors, including agriculture, construction, mining, and quarrying, the number of full-time employees must not exceed 75 , and sales turnover must not exceed RM20 million. The importance of SMEs towards the Malaysian economy is represented through the increasing number of establishments and the domination in the number of employments from year to year. According to the data reported by the Department of Statistics (DOSM), a total of 1,151,339 SMEs or $97.2 \%$ of the establishments in Malaysia in 2020 are made up of SMEs as compared to 907,065 establishments reported in 2016. There has been an increment of $4.9 \%$ of establishments every year since 2015 . Micro SMEs accounted for $78.5 \%$, followed by $20 \%$ and $1.6 \%$ firms in small and medium sizes, respectively. With regards to the number of SME establishments by sector, the services sector represents $85.5 \%$ of the total SMEs, followed by construction $(7.4 \%)$, manufacturing (5.1\%), agriculture (1.7\%), with the remaining $0.3 \%$ in the mining \& quarrying sector.

The service sector is the tertiary sector in the economy that provides services to businesses and consumers. Known as a sector that offers intangible goods, the services sector is a relative labor intensity of benefits compared to the goods-producing sector. The skills and knowledge in interaction with consumers and other stakeholders are crucial in selling intangible products. In Malaysia, the services sector forms the largest sector of SME establishments, with $85.5 \%$ of the total SME establishment. The industry comprises a wide range of industries, including wholesale and retail trade, food and beverages, accommodation, information and communication, professional and education, and arts. With the $65 \%$ domination of contribution in total value-added and employment, the services sector remains a crucial driver of growth for the Malaysian economy through the initiatives and facilities provided by the government and other parties. In the macro context, the services sector is typically skill and knowledge-based; thus, they are good sources of growth for countries with limited capital but rely on skilled and knowledgeable workforces. Despite the challenges and problems revolving around SMEs in general, the services sector is expected to grow by $7 \%$ in 2022 (Economic Outlook 2022) and enable the industry to continuously serve the nation through 
MANAGEMENT SCIENCES

Vol. 12, No. 1, 2022, E-ISSN: 2225-8329 @ 2022 HRMARS

contribution to Malaysia's GDP, employment opportunity, poverty alleviation, and entrepreneurship.

\section{Hypothesis Development}

Many prior studies have proven better firm performance by establishing and maintaining relationships with external stakeholders. The relationship between the outside organizations brings many advantages to the organization through the knowledge and insights flow into the firm. Abd-Elrahman and Kamal (2020) found that the relational capital of Egyptian telecommunication companies measured by strategic alliances, customer and supplier, customer knowledge, and marketing capabilities positively affect organizational performance. Febrian et al (2020) analyzed the effect of relational capital on SMEs' networking and marketing performance of 170 respondents as owners or managers of SMEs in Indonesia. The authors concluded that relational capital positively affects the SMEs' networking and marketing performance and portrays the need for SMEs to collaborate and synergize to develop the networks to succeed.

In another study, Yaseen et al (2016) found that relational capital positively influences the competitive advantage of the 199 Jordanian telecommunication companies. Among the intellectual capital examined, relational capital has the most substantial direct effect on the competitive advantage showing the importance of knowledge embedded in relationships with the networks.

Similarly, Sardob et al (2018) examined 934 Portuguese small and medium-sized hotels to test the effect of intellectual capital dimension hotel performance. The data were collected from 2007 to 2015. The results indicate that relational capital positively impacted hotel financial performance and was the strongest predictor towards the version more than the other components of intellectual capital. Outcomes of this study prove the relational capital as a great extension system between people in the business and others in different environments but with the same objective in delivering and gaining valuable knowledge for superior performance.

Steenkamp and Kashyap (2010) studied the perception of SME managers in New Zealand about the importance and contribution of intellectual capital components to their businesses. Relational capital and human capital were found to impact SME businesses significantly. The top ten items from the ranking analysis that were most important are customer satisfaction, customer loyalty, product reputation, corporate reputation, and relationships with suppliers. The findings indicated that relational capital is perceived as an essential contributor to SME performance in emerging economies. In another study, Daou et al (2014) provided evidence that supports Steenkamp and Kashyap's findings regarding the critical role of relational capital. The survey on 445 SME managers from three different clusters in Mexico reported clients' satisfaction, SME images, product reputation, and relationships with stakeholders appear to be the most important elements of intellectual capital. Therefore, based on the literature, the following hypothesis is proposed:

H1: Relational capital has positive relationships with SMEs' performance. 
MANAGEMENT SCIENCES

Vol. 12, No. 1, 2022, E-ISSN: 2225-8329 @ 2022 HRMARS

\section{Methodology}

This study uses primary data collected from questionnaires distributed to the respondents. The survey questionnaire consists of Sections A-C. Section A contains items of the demographic profile of the respondents and firms' characteristics, for example, type of business, whether family or non-family business, industry type, turnover, and the number of years of operation. Most of the Section $B$ and Section $C$ measures were adapted using multiitem scales from prior research. Section B contains 20 items measuring relational capital, including customers, suppliers, distribution channels, the government, and financial institutions. The measuring items were adapted from Kamukama (2013); Khalique and Pablos (2015), and Wang, Wang, and Liang (2014). Section C contains six measuring performance items adapted from Wang, Wang, and Liang (2014). This study applied subjective measurement by depending on the managers' perception of firm performance, and the respondents were asked to rate the athletic performance relative to their competitors. A fivepoint Likert scale ranging from $1=$ strongly disagree to $5=$ strongly agree was used to record the responses in Section B and Section C.

\section{Data and sample}

The respondents of this study are the managers of Malaysian SMEs in the service sector comprising various industries. Self-administered questionnaires were used to gather information on SMEs' demographic profiles and gain managers' perceptions on the topic surveyed. A set of questionnaires were delivered to 300 SMEs that were chosen using probability sampling methods. A total of 98 questionnaires were returned and usable for data analysis.

The hypothesized relationship was analyzed using SmartPLS 3.0, a software for structural equation modeling using the partial least squares path modeling method. In the PLS-SEM technique, the analysis and interpretation of the research model are distinguished into two consecutive assessment phases: the assessment of the measurement model and the assessment of the structural model. Partial Least Squares Structural Equations Modelling (PLS-SEM) is primarily used to develop theories in exploratory research or predicting purpose in a study. PLS-SEM can calculate the estimated coefficient (path coefficient) that maximizes the explained variance, R2, of endogenous latent construct or dependent variable (Hair et al., 2017).

\section{Findings and Discussions}

We discuss the findings first on the descriptive part that presents the demographic profiles of the data. The second part discusses the analytic analysis reliability and relevancy of the data.

\section{Demographic profiles}

A total of 98 responses were obtained. Of 98 respondents, 60 (61\%) SMEs were family firms, and the remainder were non-family firms. SMEs from the professional industries, including audit and legal firms, dominated with $35 \%$ of the total firms, followed by firms in ICT industries $(30 \%)$, warehouse and retails (20\%), education (10\%), and other industries $(5 \%)$. For the number of employees, 34 (35\%) SMEs have 6 to 30 employees, 33 (33\%) with 31 to 75 employees, and 32 (33\%) SMEs have 76 to 200 employees. Turnover was described as follows: RM300,000 to RM3,000,000 (22 firms), RM3,000,000 to RM15,000,000 (32 firms), RM15,000,000 to RM20,000,000 (28 firms), and RM20,000,000 to RM50,000,000 (16 firms). 
INTERNATIONAL JOURNAL OF ACADEMIC RESEARCH IN ACCOUNTING, FINANCE AND MANAGEMENT SCIENCES

Vol. 12, No. 1, 2022, E-ISSN: 2225-8329 @ 2022 HRMARS

Regarding the size of the SMEs, 51 (60\%) were categorized as small-sized while the remainder were medium in size. There were 80 (81\%) SMEs that have been in the industry for more than 11 years, and another 18 have less than 11 years of operations. Table 1 presents the demographic profile of SMEs.

Table 1. Firms' characteristics

\begin{tabular}{|l|l|l|l|}
\hline Characteristics & Types & Frequency & Percentage \\
\hline Family ownership & Family & 60 & $61 \%$ \\
\cline { 2 - 4 } & Non-family & 38 & $39 \%$ \\
\hline \multirow{5}{*}{ Industry } & Professional & 35 & $35 \%$ \\
\cline { 2 - 4 } & ICT & 30 & $30 \%$ \\
\cline { 2 - 4 } & $\begin{array}{l}\text { Warehouse and } \\
\text { retails }\end{array}$ & 20 & $20 \%$ \\
\cline { 2 - 4 } & Education & 10 & $10 \%$ \\
\cline { 2 - 4 } & Others & 5 & $5 \%$ \\
\hline \multirow{5}{*}{ Size } & 6 to 30 employees & 34 & $34 \%$ \\
\cline { 2 - 4 } & 31 to 75 employees & 33 & $33 \%$ \\
\cline { 2 - 4 } & 76 to 200 & 32 & $52 \%$ \\
\hline Years in industry & Small & 51 & $48 \%$ \\
\cline { 2 - 4 } & Medium & 47 & $81 \%$ \\
\hline & More than 11 years & 80 & $19 \%$ \\
\hline
\end{tabular}

\section{PLS-SEM analysis}

The reliability and validity of the construct's measures were assessed in the measurement model. The assessment was done by obtaining the value of outer loadings, indicator reliability, internal consistency, convergent validity, and discriminant validity (Hair et al., 2017). The indicator's outer loading should be 0.708 or higher to obtain a value that equals 0.50 through the squared loading $(0.708)^{2}$. This analysis shows that the outer loadings for all indicators were more than 0.708, ranging between 0.749 and 0.917 , thus meeting the threshold value. The composite reliability (CR) value was more than the excellent threshold value of 0.7 , and the importance of AVE was higher than 0.50. The value of AVE was higher than 0.50 , which met the proposed value of 0.50 or higher for the indicators to achieve convergent validity (Fornell \& Larcker, 1981). Summary of the results of outer loadings, AVE, and composite reliability are presented in Table 2 . Meanwhile, the discriminant validity for the research model was measured by applying Fornell \& Larcker criterion. The results indicate that the discriminant validity has been established between constructs in the model and is exhibited in Table 3.

Table 2. Reliability and Convergent Validity

\begin{tabular}{|l|l|l|l|l|}
\hline Constructs & Cronbach's Alpha & AVE & CR & $\mathbf{R}^{\mathbf{2}}$ \\
\hline $\begin{array}{l}\text { Relational } \\
\text { Capital }\end{array}$ & 0.875 & 0.784 & 0.892 & \\
\hline Performance & 0.773 & 0.861 & 0.912 & 0.433 \\
\hline
\end{tabular}


Table 3. Discriminant Validity

\begin{tabular}{|c|c|c|}
\hline & Relational Capital & Performance \\
\hline Relational Capital & 0.878 & \\
\hline Performance & 0.579 & 0.771 \\
\hline
\end{tabular}

After assessing the reliability and validity of the construct's measures, the hypothesized relationship was then examined in the structural model assessment. The bootstrapping procedures with 1,000 subsamples were conducted to examine the significance of the path coefficients and $R^{2}$ (Chin \& Dibbern, 2010). The results show that the hypothesized relationship's path coefficients $(\beta)$ have a statistically significant contribution to the model, supporting the hypothesis on the effects of relational capital and firm performance. $\mathrm{H} 1$ is supported with $\beta=0.290, p$-values $=0.012$. The $R$ squared (R2) value of 0.433 indicates the variance in the firm performance constructs explained by the relational capital construct and considered moderate (Cohen, 1992). Table 4 summarizes the results of the structural model assessment.

Table 4. Results of the significance and relevance of the structural model relationships

\begin{tabular}{|l|c|c|c|c|c|c|}
\hline & Hypotheses & $\begin{array}{c}\text { Path } \\
\text { Coefficients }\end{array}$ & $\begin{array}{c}\boldsymbol{T} \\
\text { Statistics }\end{array}$ & $\begin{array}{c}\boldsymbol{P} \\
\text { Values }\end{array}$ & $\begin{array}{c}\mathbf{9 5 \%} \\
\text { Confidence } \\
\text { Intervals }\end{array}$ & Results \\
\hline $\mathrm{H} 1 \mathrm{RC} \longrightarrow \mathrm{PERF}$ & 0.290 & 5.485 & 0.012 & 0.634 & Supported \\
\hline
\end{tabular}

This study aims to examine the relationship between relational capital and the performance of SMEs in the service sector. This study revealed that relational capital measured by customers, suppliers, partners, distribution channels, and financial providers significantly influence SMEs' economic and financial performance. This is consistent with the studies conducted in the service sector by Khalique et al (2019), who found the significant impact of relational capital on the performance of the tourism sector, Sardob, Serrasqueiroa, and Alvesa (2018) on the hotel sector, and Cohen and Kaimenakis (2007) on various industries in the service sector. This study proved that managers of SMEs are aware of the importance of developing and maintaining good relationships with their stakeholders regardless of how limited the resources they have. SMEs can establish various collaborations with other parties through the effective and efficient exchange of information and knowledge, leading to better business performance. Notably, the results indicate the ability of services SMEs to fulfill the demands according to the customers' requirements and the ability to attend to complaints and feedback from customers in a short period which leads to the customers' satisfaction and trust. Engaging in relationships with customers helps widen the firm's knowledge base, thus encouraging the firms to develop a new range of services offered by other counterparts. Additionally, the knowledge flow through collaboration with suppliers may provide further information on the current technologies and software relevant to the business in enhancing the services provided to the customers.

\section{Conclusion and Limitations}

This study indicated that relational capital measured by customers, suppliers, partners, distribution channels, and financial providers significantly influence SMEs' economic and financial performance, thus confirmed that external networks significantly affect the performance of the services SMEs in Malaysia. Insights from this study are believed to expand 
MANAGEMENT SCIENCES

Vol. 12, No. 1, 2022, E-ISSN: 2225-8329 @ 2022 HRMARS

the knowledge on how relational capital can influence SMEs' performance and simultaneously contribute to the existing literature on the subject. It shows that good interaction between SMEs and external networks positively leads to better achievement in the business's financial and non-financial aspects. The interactions with various networks help SMEs position themselves better and gain performance benefits such as increment in sales revenue and profit and building trust in the customer-supplier relationship. The study extends our understanding of the role of knowledge embedded in the relationships between the business and the third parties.

Based on the analysis, the findings suggest that owners or managers of SMEs in the service industry should invest in building and maintaining close relationships with the networks, including customers, suppliers, the government, and other stakeholders. The manager needs to strengthen the relational capital by training the employees to have more concern toward the intimate relationship with stakeholders, enhancing the knowledge on market and customer's preferences, and promoting a positive culture in serving the stakeholders. SMEs could build and sustain their reputation to ensure their credibility as the major player in the economic sector. SMEs with small employees, less complicated systems, and a less centralized organizational structure ease the knowledge sharing or delegating between the SMEs and other group members. In the case of the service sector, having close interaction with customers is one of the advantages. Overall, the rise of the knowledge-based economy requires SMEs to nurture sufficient tangible resources and intellectual resources to enhance their performance.

This study has some limitations that future research may overcome. The sample of SMEs in this study only focuses on one specific sector and country, hence restricting the generalizability to SMEs in other sectors. Other sectors such as manufacturing and agriculture might provide different relational capital and performance results due to the distinguishing characteristics. Examining the relationship between SMEs network and performance on all types of SME is recommended to promote generalizability. Next, this study used the crosssectional design where the data was collected at a single point of time. This limitation may not capture the changes related to relational capital elements and firm performance. For future research, a longitudinal study is proposed for investigating the relational capital patterns within a firm over time.

\section{References}

Abd- El-Rahman, A. H., \& Kamal, A. J. M. (2020). Relational capital, service quality, and organizational performance in the Egyptian telecommunication sector. International Journal of Emerging Markets. Volume ahead -of-prints

Aziz, T. N., Razalli, M. R., and Othman, A. Z. (2019). The impact of relational capital as an essential instrument of increasing competitiveness on balanced scorecard performance in a life insurance agency in Malaysia. International Journal of Academic Research in Business and Social Sciences, 9(12), 495-505.

Barney, J. (1991). Firm resources and sustained competitive advantage. Journal of Management 17(1), 99-120.

Bontis, N. (1998). Intellectual capital: an exploratory study that develops measures and models. Management Decision 36(2), 63-76. doi:10.1108/00251749810204142 
MANAGEMENT SCIENCES

Vol. 12, No. 1, 2022, E-ISSN: 2225-8329 ๔ 2022 HRMARS

Bontis, N. (1999). Managing organizational knowledge by diagnosing intellectual capital: framing and advancing the state of the field. Int. J. Technology Management, 18(5/6/7/8), 433-463.

Cabrilo, S., Dahms, S., Mutuc, B. E., and Marlin, J. (2020). The role of IT practices in facilitating relational and trust capital for superior innovation performance: The case of Taiwanese companies. Journal of Intellectual Capital, 21 (5), 753-779.

Cabrita, M. do R., \& Bontis, N. (2008). Intellectual capital and business performance in the Portuguese banking industry. Int. J. Technology Management 43(1-3), 212-237.

Capello, R., Faggian, A. (2005), Collective learning and relational capital in local innovation processes. Regional Studies, 39(1), 75-80.

Chin, W. W., \& Dibbern, J. (2010). Handbook of Partial Least Squares. Handbook of Partial Least Squares. doi:10.1007/978-3-540-32827-8.

Cohen, J. (1992). A power primer. Psychological Bulletin, 1121.

Cohen, S., \& Kaimenakis, N. (2007). Intellectual capital and corporate performance in knowledge-intensive SMEs. The Learning Organization, 14, 241-262. doi:10.1108/09696470710739417.

Daou, A., Karuranga, E., \& Su, Z. (2014). Towards a better understanding of intellectual capital in Mexican SMEs. Journal of Intellectual Capital, 15(2), 316-332. doi:10.1108/JIC-082013-0092.

Febriana, A. C., Sukresnaa, I. M., \& Ghozali, I. (2020). Relational capital and marketing performance: The mediating role of SMEs networking in Indonesia. Management Science Letters, 10 (2020) 3405-3412.

Fornell, C., \& Larcker, D. F. (1981). Evaluating structural equation models with unobservable variables and measurement error. Journal of Marketing Research, 18(1), 39-50.

Hair, J., Hult, T., Ringle, C., \& Sarstedt, M. (2017). A primer on Partial least squares structural equation modeling (PLS-SEM). Second Edi. Los Angeles: SAGE. doi:10.1108/EBR-102013-0128.

Jain, P., Vyas, V., \& Roy, A. (2017). Exploring the mediating role of intellectual capital and competitive advantage on the relation between CSR and financial performance in SMEs. Social Responsibility Journal, 13(1),1-23. doi.org/10.1108/SRJ-04-2015-0048.

Kamukama, N. (2013). Intellectual capital: company's invisible source of competitive advantage. Competitiveness Review: An International Business Journal 23(3), 260-283. doi:10.1108/10595421311319834.

Khalique, M., \& Pablos, P. O. (2015). Intellectual capital and performance of electrical and electronics SMEs in Malaysia. Int. J. Learning and Intellectual Capital, 12(3), 251-269. doi:10.1504/IJLIC.2015.070166.

Khalique, M., Bontis, N., Shaari, J. A. N., \& Isa, M. A. H. (2015). Intellectual capital in small and medium enterprises in Pakistan. Journal of Intellectual Capital, 16(1), 224-238.

Khalique, M., Hina, K., Ramayah, T., \& Shaari, J. A. N. (2019). Intellectual capital in tourism SMEs in Azad Jammu and Kashmir, Pakistan. Journal of Intellectual Capital, 21(3), 333355.

Kianto, A., Hurmelinna-laukkanen, P., \& Ritala, P. (2010). Intellectual capital in service- and product-oriented companies. Journal of Intellectual Capital, 11(3), 305-325. doi:10.1108/14691931011064563

Marzo, G., \& Scarpino, E. (2016). Exploring intellectual capital management in SMEs: An indepth Italian case study. Journal of Intellectual Capital, 17(1), 27-51.

Ministry of Finance. (2021). Economic Outlook 2022. Malaysia 
Peltier, J. W., \& Naidu, G. M. (2012). Social networks across the SME organizational lifecycle. Journal of Small Business and Enterprise Development 19(1), 56-73. doi:10.1108/14626001211196406

Petty, R., \& Guthrie, J. (2000). Intellectual capital literature review: Measurement, reporting, and management. Journal of Intellectual Capital, 1(2), 155-176.

Sardob, F., Serrasqueiroa, Z., \& Alvesa, H. (2018). On the relationship between intellectual capital and financial performance: A panel data analysis on SME hotels. International Journal of Hospitality Management. 75, 67-74

Saxena, G. (2015). Imagined relational capital: an analytical tool in considering small tourism firm's sociality. Tourism Management, 40, 109-118

Steenkamp, N., \& Kashyap, V. (2010). Importance and contribution of intangible assets: SME managers perceptions. Journal of Intellectual Capital, 11(3), 368-390. doi:10.1108/14691931011064590

Sveiby, K. E. (1997). The new organization wealth: Managing and measuring knowledge-based assets. New York: Berrett-Koehler.

Sveiby, K.-E. (2001). A knowledge-based theory of the firm to guide in strategy formulation. Journal of Intellectual Capital, 2(4), 344-358. doi:10.1108/14691930110409651

Welbourne, T. M. (2008). Manuela pardo-del-val relational capital: strategic advantage for Small and Medium-Size Enterprises (SMEs) through negotiation and collaboration. Group decision and negotiation, 18, 483-497.

Wang, Z., Wang, N., \& Liang, H. (2014). Knowledge sharing, intellectual capital and firm performance. Management Decision, 52(2), 230-258. doi:10.1108/MD-02-2013-0064

Yaseen, S. G., Dajani, D., \& Hasan, Y. (2016). The impact of intellectual capital on the competitive advantage. Computers in Human Behavior, 62 (2016,) 168-175 